\title{
Hemşirelik Öğrencilerinin Covid-19 Pandemi Sürecinde Sağlık Bilişleri ile Depresyon Anksiyete Stres Düzeyleri Arasındaki İlişkisi
}

\section{The Relationship among Nursing Students' Health Cognitions for Covid-19 Pandemia and Depression Anxiety Stress Levels}

\author{
Alev Yildirim Keskin ${ }^{1 *}$, Birsel Molu ${ }^{1}$ \\ ${ }^{1}$ Selçuk Üniversitesi, Akşehir Kadir Yallagöz Sağlık Yüksekokulu, Konya, Türkiye \\ e-mail: alevyildirim@selcuk.edu.tr, brslml@hotmail.com \\ ORCID: 0000-0003-0981-5364 \\ ORCID: 0000-0001-5144-286X \\ *Sorumlu yazar/ Corresponding Author: Alev Yildirim Keskin \\ Gönderim Tarihi / Received: 17.09.2020 \\ Kabul Tarihi / Accepted: 23.11.2020 \\ DOI: $10.34087 /$ cbusbed. 796470
}

\begin{abstract}
Giriş ve Amaç: Hemşirelik öğrencilerinin Covid-19 pandemi sürecinde sağlık bilişleri ile depresyon, anksiyete ve stres düzeyleri arasındaki ilişkiyi saptamak amacıyla yapılmıştır.

Gereç ve Yöntemler: Tanımlayıcı ve kesitsel nitelikte olan bu çalışmanın evrenini hemşirelik birinci, ikinci, üçüncü ve dördüncü sınıfta okuyan toplam 245 öğrenci, örneklemini ise 20.06.2020-20.07.2020 tarihleri arasında araştırmaya katılmayı kabul eden 175 öğrenci oluşturmuştur. Veriler araştırmacılar tarafından oluşturulan veri toplama formu, Depresyon Anksiyete Stres (DASS-21) ve Sağlık Bilişleri Ölçeği ile toplanmıştır. Verilerin tanımlayıcı istatistikleri hesaplanmış ve Mann-Whitney U testi, Kruskal-Wallis testi, Post Hoc testlerden Dunn Bonferroni, Spearman Korelasyon analizi uygulanmıştır.

Bulgular: Öğrencilerin Depresyon Anksiyete Stres Ölçeği (DASS-21) toplam puan ortalamasının 15.58 \pm 11.78 ,

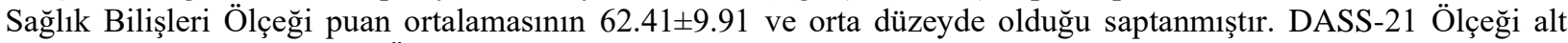
boyutları ile Sağlık Bilişleri Ölç̧eği alt boyutları arasında anlamlı bir ilişki bulunmuştur $(\mathrm{p}<0,05)$.

Sonuç: Bu çalışma hemşirelik öğrencilerinin depresyon, anksiyete, stres ve sağlık bilişi arasında bir ilişkisi olduğunu göstermiştir. Hemşirelik öğrencilerine hemşirelik eğitmenleri tarafından eğitim verilmesi ve psikolojik destek sağlanması önerilmektedir.
\end{abstract}

Anahtar kelimeler: Anksiyete, Covid-19, Depresyon, Öğrenci, Sağlık Bilişi, Stres.

\footnotetext{
Abstract

Objective It was conducted to determine the relationship between the health cognition and depression, anxiety and stress levels of the nursing students during the Covid-19 pandemic process.

Materials and Methods The population of this descriptive and cross-sectional study consisted of 245 students studying in the first, second, third and fourth years of nursing and the sample of 175 students who agreed to participate in the study between 20.06.2020-20.07.2020. The data were collected by the data collection form created by the researchers, Depression Anxiety Stress (DASS-21) and Health Cognition Scale. Descriptive statistics of the data were calculated and in the statistical analysis and Mann-Whitney U test, Kruskal-Wallis test, Dunn Bonferroni, Post Hoc tests, Spearman Correlation analysis were applied.

Results: It was determined that the total score average of the students' Depression Anxiety Stress Scale (DASS-21) was $15.58 \pm 11.78$, and the Health Cognition Scale (HCS) average score was $62.41 \pm 9.91$. A significant relation was found between the DASS-21 Scale subscales and the Health Cognition Scale subscales $(\mathrm{p}<0.05)$.

Conclusion: This study showed that there is a relationship between nursing students' depression, anxiety, stress and health cognition. It is recommended that nursing students be trained by nursing instructors and provide psychological support.
}

Keywords: Anxiety, Covid-19, Depression, Health Cognition, Stress, Student. 


\section{Giriş}

Çin'in Wuhan şehrinde 31 Aralık 2019 yılında salgını oluşturan virüsün Coronaviridae ailesine ait olduğu bildirilmiştir [1, 2]. Uluslararası Virüs Taksonomisi Komitesi Coronavirus Çalışma Grubu, virüsü ilk olarak 2019-nCoV olarak adlanmıştır [3]. Dünya Sağlık Örgütü ise, 11 Şubat 2020 'de virüsün neden olduğu salgını coronavirus hastalığ 2019 (COVID-19) olarak adlandırmıştır ve ülkemizde ilk vaka 11 Mart 2020'de saptanmıştır [4]. Virüs insanda ateş, öksürük, nefes darlığı gibi semptomlar ve çeşitli derecelerde enterik, hepatik, nefrotik ve nörolojik tutulumlarla seyreden klinik tablolara neden olabilmektedir [4-6].

İnsanlarla yakın temasta bulunan tüm çalışan grubu gibi sağlık profesyonelleri de her zaman bulaşıcı hastalık ve hastalığın getirdiği depreson, anksiyete ve stres riski altındadır. Covid-19'un muhtemelen asemptomatik bireylerden bile bulaşabileceğini bilerek risk çoğalmaktadır $[5,7,8]$. Sağlık profesyonelleri arasında yer alan hemşirelik öğrencileri de klinik uygulamaları nedeniyle etkilenen insanlarla yakın temasta bulunabilecek ilk kişilerdir. Hemşirelik öğrencilerinin pandemi ile ilgili sağlık biliş düzeyleri, bilgi eksikliği onların stres ve kaygı düzeylerini artırarak tıbbi karar vermelerini olumsuz etkilemektedir [9]. Anksiyete, stres, kayg1, depresyon gibi psikolojik durumların sağlık üzerine etkisinin fark edilmesiyle sağlık bilişleri kavramı ortaya çıkmıştır. Hastalığın olasılığı, hastalığın korkunçluğu, hastalık ile baş etme zorluğu ve sağlık hizmetlerinin yetersizliği kategorileri ile elde edilen alg1, bireyin sağlığa ilişkin bilişlerini anlamamızı sağlamaktadır [10].

Yaşadığımız dönem dolayısıyla karantina günlerinde sağlık hizmeti veren üniversitede okuyan hemşirelik öğrencilerinin sağlık biliş (hastalık olasılıklarını, hastalığın korkunçluğu, hastalık ile baş etme zorluğu, sağlı hizmetlerinin yetersizliği) algılarının saptanması, sağlık algılarının anksiyete, depresyon ve stres durumlarına etkisinin belirlenmesi, öğrencilerin kliniklerde hasta bireylerle karşılaşacak olmaları daha fazla dikkatli olmaları ve kendilerin ve çevrelerinin de sağlıklı yaşam koşullarını kazanmaları açısından önemlidir. Literatür taraması sonucu ülkemizde bu konuda yapılan bir çalışmaya rastlanmamıştır. Buradan yola çıkarak bu çalışmada hemşirelik öğrencilerinin sağlık biliş düzeylerinin değerlendirilmesinin pandemi sürecinde stres depresyon anksiyete yaşama düzeylerinin anlaşılmasının literatüre katk1 sağlayacağı düşünülmektedir. $\mathrm{Bu}$ nedenle bu çalışma Covid-19 pandemisine yönelik hemşirelik öğrencilerinin sağlık bilişleri ile depresyon anksiyete stres düzeyleri arasındaki ilişkiyi belirlemek amacıyla yapılmıştır.

\section{Materyal ve Metot}

\subsection{Araştırmanın tipi}

Araştırma, kesitsel tanımlayıcı tipte yapılmıştır.

2.2. Araştırmanın evren ve örneklemi

Araştırmanın evrenini 2019-2020 bahar yarıyılında Akşehir Kadir Yallagöz Sağlık Yüksekokulu Hemşirelik Bölümü'nde öğrenim gören tüm öğrenciler oluşturmuştur. Araştırmanın evrenini hemşirelik birinci, ikinci, üçüncü ve dördüncü sinifta okuyan toplam 245 öğrenci, örneklemini ise 20.06.2020-20.07.2020 tarihleri arasında araştırma iletişime açık, çalışmaya katılmayı kabul eden 175 öğrenci oluşturmuştur. Araştırmaya katılmak istemeyen (54), formları eksik dolduran (10), araştırmaya katılmaktan vazgeçen (6) öğrenciler çalışma dışı bırakılmıştır. Evrenin \% 71.4'üne ulaşılmıştır.

\subsection{Veri Toplanmas}

Veriler, araştırmacılar tarafindan literatür doğrultusunda hazırlanan veri toplama formu ile toplanmıştır $[6,10,11$, $12,13]$. Salgın sirasında tavsiye edilen spesifik önlemler nedeniyle, yakın temas ve dokunma önlemleri dahil olmak üzere, bu önerileri takip etmek için çevrimiçi bir anket tasarlanmıştır. Covid-19 pandemisi nedeniyle ögrencilere anket uygulaması google form üzerinden oluşturulan link ile yapılmıştır. Veri toplama formu dört bölümden oluşmaktadır: Demografik veriler, Covıd-19 ile ilgili bilgiler, Sağlık Bilişleri Ölçeği ve Depresyon Anksiyete Stres (DASS-21) Ölçeğini içermektedir. Demografik veriler; yaş, cinsiyet, sınıf, gelir düzeyi, kronik hastalık durumu, Covid-19 ile eğitim alma durumunu içermektedir. Verilerin toplama süresi her bir öğrenci için yaklaşık 15-20 dakika olarak ayarlanmıştır. 2.3.1. Veri Toplama Formu

Literatür taranarak hazırlanan veri toplama formunda [6, $10,11,12,13]$ öğrencilerin sosyodemografik özelliklerini içeren 10 soru (yaş, cinsiyet, sınıf, gelir düzeyi, yaşadığı yer, kronik hastalık durumu, sigara ve alkol kullanma durumu) ile Covid-19 hakkında eğitim alma ve Covid-19 hastalığının öğrenciler üzerinde anksiyete, stres yaratma durumu belirlemek üzere 10 soru olarak toplam 20 sorudan oluşmaktadır.

\subsubsection{Să̆lık Bilişleri Ölçeği}

Ölçeğin orijinal formu Hadjistavropoulos ve arkadaşları, (2012) tarafından geliştirilmiştir. Ölçeğin İngilizce Orjinal formu 20 sorudan oluşup 5'li likert tipinde, 4 faktörlü bir yapıdadır. Ölçekte ters kodlanan madde bulunmamaktadır. Ölçekten alınan puan 20 ila 100 arasında değişmektedir. Puanın yükselmesi bireyin sağlık kaygısına ilişkin irrasyonel düşüncelerin varlığını göstermektedir. Doğrulayıcı faktör analizleri sonucunda ise, Sağlık Bilişleri Ölçeği'nin tümü için hesaplanan Cronbach's Alpha iç tutarlık katsayısı ise 0.821 olarak hesaplanmıştır. Ölçeğin Türkçe geçerlik güvenirlik çalışması Altay ve Yüksel tarafından (2019) yılında yapılmıştır. Bu çalışmada ölçeğin Cronbach Alpha değerinin 0.78 olduğu tespit edilmiştir.

\subsubsection{Depresyon Anksiyete Stres Ölçeği}

Lovibond ve Lovibond tarafından geliştirilen Depresyon Anksiyete Stres Ölçeği (DASS) 42 maddeden oluşmaktadır [14]. Ölçek 4'lü likert tipi bir derecelendirmeye sahiptir. Bu formun Türkçe uyarlaması ise Yılmaz, Boz \& Arslan tarafindan 2017 yılında yapılmıştır (Yılmaz, Boz \& Arslan, 2017). Analiz sonuçlarına göre ölçeğin faktör yüklerinin, 41 ile 81 arasında değiştiği görülmektedir. Ölçeğin puanlamasında depresyon 0-4 puan, anksiyete 0-3 puan, stres 0-7 puan normal düzey; depresyon 5-6, anksiyete 4-5, stres 8-9 puan hafif düzey; depresyon 7-10, anksiyete 5-7, stres 
10-12 puan orta düzey; depresyon 11-13, anksiyete 8-9, stres 13-16 puan ileri düzey; depresyon 14 ve üzeri paun, anksiyete 10 ve üzeri puan, stres 17 ve üzeri puan çok ileri düzey probleme sahip olduğunu göstermektedir (Yılmaz, Boz \& Arslan, 2017). Bu çalışmada ölçeğin Cronbach Alpha değerinin 0.91 olduğu tespit edilmiştir.

\subsection{Verilerin Analizi}

Veri toplama formundan elde edilen veriler Statistical Package for the Social Sciences (SPSS) 24 programında değerlendirilmiştir. Verilerin tanımlayıcı istatistikleri hesaplanmış ve normallik dağılımı için KolmogorovSmirrnov testi uygulanmıştır. İstatistiksel analizde öğrencilerin sosyodemografik özelliklerinin değerlendirilmesinde sayı, yüzde, standart sapma, frekans, ortalama, minimum-maksimum değerlerin hesaplanmıştır. Korelasyon incelemeleri için normal dağ 11 ım göstermeyen verilerde Spearman Korelasyon analizi uygulanmıştır. Normal dağılım göstermeyen değişkenler için bağımsız iki grubun karşılaştırmasında Mann-Whitney U testi, bağımsız üç ve üzeri grubun karşılaştırılmasında Kruskal-Wallis testi uygulanmış, gruplar arasındaki farkı belirlemek için ise Post-Hoc testlerden Dunn Bonferroni testi kullanılmıştır. Testlerin anlamlılık düzeyi olarak $\mathrm{p}<0,05$ kabul edilmiştir.

2.5. Araştırmanın Etik Boyutu: Araştırmanın uygulanabilmesi ve verilerin toplanabilmesi amaci ile Sağlık Bakanlığı Bilimsel Araştırma Platformu'ndan (2020-05-10T11-42-10) sayılı izin, Akşehir Kadir Yallagöz Sağlı Yüksekokulu'ndan (11/05/2020E.39230, 85336622-044/say1lı izin), Selçuk Üniversitesi Sağlık Bilimleri Fakültesi Yerel Etik Kuruldan (2020/254 karar sayılı) izinler alınmıştır. Araştırma için hazırlanan çevrimiçi link üzerinden öğrencilere, araştırmanın amacı, süreci ve anket formu hakkında açıklamalar yapılmış, araştırmaya katılımın gönüllülük esasına dayandığ 1 belirtilerek öğrencilerin de onamları alınmıştır. $\mathrm{Bu}$ araştırma, Helsinki Deklerasyonu Prensipleri dikkate alınarak yapılmıştır.

\section{Bulgular ve Tartışma \\ 3.1 Bulgular}

Tablo1'de araştırmaya katılan hemşirelik öğrencilerinin sosyo-demografik özelliklere göre dağılımı verilmiştir. Öğrencilerin \%56.5'inin 18-20 yaş aralığında, \%84.6'sının kadın, \%42.3'ünün hemşirelik 2.sınıf, $\% 82.3$ 'ünün gelir düzeyinin orta, \%60.0'1nın yurtta kaldığı, \%98.9'unun herhangi bir kronik hastalığının olmadığ1, \%85.7'sinin sigara ve \%90.3'ünün alkol kullanmadığı, \%74.9'unun Covid-19 hakkında eğitim almadığ1, \%81.7'sinin Covid-19 nedeniyle stres ve anksiyete yaşadıkları belirlenmiştir (Tablo 1).

Tablo 2'de araştırmaya katılan hemşirelik öğrencilerinin DASS-21 ölçeği depresyon alt boyut puan ortalaması 5.84 \pm 6.29 , (min:0, max:21), cronbach alfa değeri 0.93; anksiyete alt boyut puan ortalamas1 $2.79 \pm 2.74$, (min:0, max:10), cronbach alfa değeri 0.65 ; stres alt boyut puan ortalamas1 $7.42 \pm 5.61$, (min:0, max:21), cronbach alfa değeri 0.88 olarak bulunmuştur. DASS-21 ölçeği toplam puan ortalamas1 ise, $15.58 \pm 11.78$, (min:0, max:46), cronbach alfa değeri 0.91 olarak saptanmıştır.
Tablo 1. Hemşirelik Öğrencilerinin Sosyo-demografik Özelliklere Göre Dağılımı (N=175)

\begin{tabular}{|c|c|c|}
\hline $\begin{array}{l}\text { Sosyo-demografik } \\
\text { Özellikler }\end{array}$ & $\mathbf{N}$ & $\%$ \\
\hline $\begin{array}{l}\text { Yaş (Min:18, Max:23) } \\
18-20 \text { yaş } \\
21-23 \text { yaş }\end{array}$ & $\begin{array}{l}99 \\
76\end{array}$ & $\begin{array}{l}56.5 \\
43.5\end{array}$ \\
\hline $\begin{array}{l}\text { Cinsiyet } \\
\text { Kadin } \\
\text { Erkek }\end{array}$ & $\begin{array}{c}148 \\
27\end{array}$ & $\begin{array}{l}84.6 \\
15.4\end{array}$ \\
\hline $\begin{array}{l}\text { Sinıf } \\
\text { 1.Sinıf } \\
\text { 2.Sinıf } \\
\text { 3.Sinıf } \\
\text { 4.Sinif }\end{array}$ & $\begin{array}{l}53 \\
74 \\
34 \\
14\end{array}$ & $\begin{array}{r}30.3 \\
42.3 \\
19.4 \\
8.0\end{array}$ \\
\hline $\begin{array}{l}\text { Gelir düzeyi } \\
\text { İyi } \\
\text { Orta } \\
\text { Kötü }\end{array}$ & $\begin{array}{r}15 \\
144 \\
16\end{array}$ & $\begin{array}{r}8.6 \\
82.3 \\
9.1\end{array}$ \\
\hline $\begin{array}{l}\text { Yaşadığı yer } \\
\text { Yurt } \\
\text { Ev } \\
\text { Aile yanı }\end{array}$ & $\begin{array}{r}105 \\
62 \\
8\end{array}$ & $\begin{array}{r}60.0 \\
35.4 \\
4.6\end{array}$ \\
\hline $\begin{array}{l}\text { Kronik } \\
\text { durumu hastalık } \\
\text { Var } \\
\text { Yok }\end{array}$ & $\begin{array}{r}2 \\
173\end{array}$ & $\begin{array}{r}1.1 \\
98.9\end{array}$ \\
\hline $\begin{array}{l}\text { Sigara kullanma } \\
\text { durumu } \\
\text { Kullaniyorum } \\
\text { Kullanmiyorum }\end{array}$ & $\begin{array}{r}25 \\
150\end{array}$ & $\begin{array}{l}14.3 \\
85.7\end{array}$ \\
\hline $\begin{array}{l}\text { Alkol kullanma } \\
\text { durumu } \\
\text { Kullaniyorum } \\
\text { Kullanmiyorum }\end{array}$ & $\begin{array}{r}17 \\
158\end{array}$ & $\begin{array}{r}9.7 \\
90.3\end{array}$ \\
\hline $\begin{array}{l}\text { Covid-19 hakkında } \\
\text { eğitim alma durumu } \\
\text { Evet } \\
\text { Hayır }\end{array}$ & $\begin{array}{r}44 \\
131\end{array}$ & $\begin{array}{l}25.1 \\
74.9\end{array}$ \\
\hline 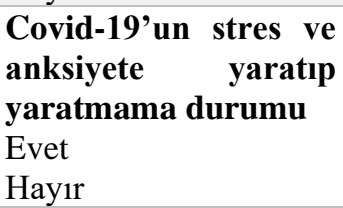 & $\begin{array}{r}143 \\
32\end{array}$ & $\begin{array}{l}81.7 \\
18.3\end{array}$ \\
\hline
\end{tabular}

Hemşirelik öğrencilerinin Sağlık Bilişleri Ölçeği'nin

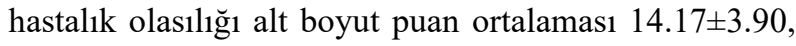
(min:5, max:20), cronbach alfa değeri 0.77, hastalığın korkunçluğu alt boyut puan ortalaması 15.17 \pm 2.90 , (min:9, max:33), cronbach alfa değeri 0.83; hastalık ile başa çıkma zorluğu alt boyut puan ortalaması 25.28 $\pm 4.88,(\min : 5, \max : 17)$, cronbach alfa değeri 0.70; sağlık hizmetlerinin yetersizliği alt boyut puan ortalaması 11.13 \pm 2.62 , (min:5, max:20), cronbach alfa değeri 0.65 olarak saptanmıştır. Sağlık Bilişleri Ölçeği toplam puan ortalamas1 ise, $62.41 \pm 9.91$, (min:27, $\max : 81)$, cronbach alfa değeri 0.78 olarak bulunmuştur (Tablo 2). 
Tablo 2: DASS-21 ve Sağlık Bilişleri Ölçeğinden Elde edilen Puanlara İlişkin Tanımlayıcı Özellikler ( $\mathrm{N}=175)$

\begin{tabular}{|c|c|c|c|}
\hline $\begin{array}{l}\text { DASS-21 Alt } \\
\text { Boyutları }\end{array}$ & $\begin{array}{c}\text { Min- } \\
\operatorname{Max} / \mathbf{N}\end{array}$ & $\mathbf{X} \pm \mathbf{S S}$ & $\begin{array}{c}\text { Cronbach } \\
\text { Alfa }\end{array}$ \\
\hline Depresyon & $\begin{array}{c}0-21 \\
175\end{array}$ & $5.84 \pm 6.29$ & 0.93 \\
\hline Anksiyete & - 10 & $2.79 \pm 2.74$ & 0.65 \\
\hline Stres & $\begin{array}{c}0-10 \\
175\end{array}$ & $7.42 \pm 5.61$ & 0.88 \\
\hline & $\begin{array}{c}0-21 \\
175\end{array}$ & & \\
\hline $\begin{array}{l}\text { DASS-21 } \\
\text { Toplam }\end{array}$ & $\begin{array}{c}0- \\
46 / 175\end{array}$ & $15.58 \pm 11.78$ & 0.91 \\
\hline \multicolumn{4}{|c|}{ Sağlık Bilişleri Ölçeği Alt Boyutları } \\
\hline $\begin{array}{l}\text { Hastalık } \\
\text { olasılığı }\end{array}$ & $\begin{array}{c}5-20 \\
175\end{array}$ & $14.17 \pm 3.90$ & 0.77 \\
\hline Hastalığın & $5-20$ & $15.17 \pm 2.90$ & 0.83 \\
\hline korkunçluğu & 175 & $25.28 \pm 4.88$ & 0.70 \\
\hline $\begin{array}{l}\text { Hastalık ile } \\
\text { başa çıkma } \\
\text { zorluğu } \\
\text { Sağlık } \\
\text { hizmetlerinin } \\
\text { yetersizliği }\end{array}$ & $\begin{array}{c}9-33 \\
175 \\
5-20 \\
175\end{array}$ & $11.13 \pm 2.62$ & 0.65 \\
\hline $\begin{array}{l}\text { Sağlık } \\
\text { Bilişleri } \\
\text { Ölçeği } \\
\text { Toplam }\end{array}$ & $\begin{array}{c}27-81 \\
175\end{array}$ & $62.41 \pm 9.91$ & 0.78 \\
\hline
\end{tabular}

*Min: Minimum, Max. Maksimum, X: Ortalama, SS: Standart sapma
Tablo 3'de hemşirelik öğrencilerinin DASS-21 düzeylerine göre dağılımına bakıldığında; hemşirelik ögrencilerinin \%41.1'inin depresyon düzeyinin normal olduğu, \%12.6'sinın hafif, \%12.6'sinin orta ve $\% 8.6$ 'sının ileri düzey ve \%25.1'inin çok ileri düzey depresyon yaşadıkları saptanmıştır. Hemşirelik öğrencilerinin \%77.1'inin anksiyete düzeyinin normal, $\% 9.7$ 'sinin hafif ve \%13.2' sinin orta düzey olduğu tespit edilmiştir. Öğrencilerin \%53.1'inin stres düzeyinin normal, \%9.7'sinin hafif, \%16.6'sinın orta, \%13.1'inin ileri ve \%7.4'ünün ise çok ileri düzeyde olduğu saptanmıştır.

Tablo 4'de hemşirelik öğrencilerinin DASS-21 ve Sağlık Bilişleri Ölçeği'nden aldıkları puanların bazı değişkenler açısından karşılaştırılmasına bakıldığında; öğrencilerin cinsiyeti ile DASS-21 Ölçeği anksiyete alt boyutu arasında anlamlı bir ilişki ( $\mathrm{p}=0.001)$ saptanmıştır. Kadın öğrencilerin $(3.08 \pm 2.84)$ erkek öğrencilere göre $(1.22 \pm 1.28)$ anksiyete puanlarının daha yüksek olduğu belirlenmiştir. Çalışmaya katılan öğrencilerin sınıf düzeyleri arttıkça DASS-21 stres alt boyutundan aldıkları puanların sirasıyla azaldığ $(9.07 \pm 6.03 ; 6.21 \pm 4.68$; $7.79 \pm 6.36 ; 6.71 \pm 5.41)$ ve aralarında anlamlı bir ilişkinin olduğu ( $p=0.040)$ tespit edilmiştir. Öğrencilerin sigara ve alkol kullanma durumları ile DASS-21 anksiyete alt boyutu arasında sırasıyla anlamlı bir ilişki $(\mathrm{p}=0.003$; $\mathrm{p}=0.004$ ) saptanmıştır. Sigara kullanan öğrencilerin $(1.28 \pm 1.36)$ sigara kullanmayan öğrencilere göre $(3.04 \pm 2.83)$ ve alkol kullanan öğrencilerin (1.00 \pm 0.86$)$ kullanmayanlara göre $(2.98 \pm 2.81)$ anksiyete alt boyutundan aldıkları puanların daha düşük olduğu belirlenmiştir. Öğrencilerin alkol kullanma durumları ile DASS-21 stres alt boyutu arasında anlamlı bir ilişki $(\mathrm{p}=0.044)$ saptanmıştır. Alkol kullanan öğrencilerin $(9.52 \pm 4.40 ; \quad 7.20 \pm 5.69) \quad$ stres düzeylerinin kullanmayanlara göre daha yüksek olduğu tespit edilmiştir. Öğrencilerin yaşı, sınıf düzeyi, yaşadığı yer, Covid-19 hakkında eğitim alma durumu ile Sağlık Bilişleri Ölçeği’nin sağlık hizmetlerinin yetersizliği alt boyutu arasinda sirasiyla $(\mathrm{p}=0.000, \mathrm{p}=0.011, \mathrm{p}=0.030$, $\mathrm{p}=0.003$ ) anlamlı bir ilişki saptanmıştır.

Tablo 3. Hemşirelik Öğrencilerinin Depresyon Anksiyete Stres (DASS-21) Düzeylerinin Dağılımı (n=175)

\section{DASS-21}

\begin{tabular}{|l|c|r|r|r|r|r|}
\hline \multicolumn{2}{|c|}{ Depresyon } & \multicolumn{2}{c|}{ Anksiyete } & \multicolumn{2}{c|}{ Stres } \\
\hline Düzey & n & \% & n & \% & n & \% \\
\hline Normal & 72 & 41.1 & 135 & 77.1 & 93 & 53.1 \\
Hafif & 22 & 12.6 & 17 & 9.7 & 17 & 9.7 \\
Orta & 22 & 12.6 & 23 & 13.2 & 29 & 16.6 \\
İleri & 15 & 8.6 & - & - & 23 & 7.4 \\
Çok İleri & 44 & 25.1 & - & - & & 13 \\
& & & & & & \\
\hline
\end{tabular}


Yaşları ve sınıf düzeyleri küçük olan öğrencilerin $(11.68 \pm 2.76 ; 11.81 \pm 2.50)$ yaşı ve sınıf düzeyi büyük olanlara göre $(10.42 \pm 2.26 ; \quad 9.50 \pm 1.74) \quad$ sağllk hizmetlerinin daha yetersiz olduğunu düşünmektedir. Sınıf düzeyi yükseldikçe sağlık hizmetlerinin yetersizliğine ilişkin öğrencilerin puanlarının azaldığ saptanmıştır. Cinsiyet ile DASS-21 Ölçeği anksiyete alt boyutu arasında $(\mathrm{p}=0.001)$ anlamlı bir ilişki saptanmıştır. Kadın öğrencilerin (11.27 \pm 2.71$)$ erkek öğrencilere göre $(10.37 \pm 1.98)$ sağlık hizmetlerinin yetersizliği alt boyutundan aldıkları puanların daha yüksek olduğu tespit edilmiştir. Kadınların erkeklere göre anksiyete puanlarının daha yüksek olduğu belirlenmiştir. Yurtta kalan öğrencilerin Sağlık Bilișleri Ölçeği’nin sağlık hizmetleri yetersizliği alt boyutundan aldıkları puanların (11.32 \pm 2.62$)$, aile yanında kalan öğrencilere göre daha yüksek olduğu $(8.62 \pm 2.13)$ ve aralarındaki ilişkinin anlamlı olduğu $(\mathrm{p}=0.030)$ tespit edilmiştir. Yurtta kalan öğrenciler aile yanında kalanlara göre sağlık hizmetlerinin daha yetersiz olduğunu ifade etmişlerdir. Öğrencilerin yaşadıkları yer ile hastalık ile başa çıkma zorluğu alt boyutu arasında anlamlı bir ilişki $(\mathrm{p}=0.017)$ saptanmıștır. Yurtta kalan öğrencilerin hastalık ile başa çıkma alt boyut puan ortalamalarının ev ve aile yanında kalan öğrencilere göre sirasiyla (25.51 \pm 4.94 ; $25.35 \pm 4.87 ; 21.75 \pm 2.60)$ daha yüksek olduğu tespit edilmiştir. Öğrencilerin sigara ve alkol kullanma durumları ile hastalık ile başa çıkma zorluğu alt boyutu arasında sırasıyla $(\mathrm{p}=0.000 ; 0.036)$ anlamlı bir ilişki saptanmıştır. Sigara ve alkol kullanan öğrencilerin hastalık ile başa çıkma alt boyutundan aldıkları puanların $(29.28 \pm 2.57 ; 27.94 \pm 3.45)$ kullanmayanlara oranla daha yüksek olduğu $(24.62 \pm 4.86 ; 25.00 \pm 4.93)$ tespit edilmiştir. Öğrencilerde Covid-19'un anksiyete ve stres yaratma durumu ile hastalıkla başa çıkma zorluğu alt boyutu arasında da anlamlı bir ilişki tespit edilmiştir $(\mathrm{p}=0.017)$. Covid-19 anksiyete ve stres yaratiyor diyen öğrencilerin $(25.00 \pm 4.55)$ yaratmıyor diyen öğrencilere göre $(26.53 \pm 6.06)$ hastalıkla başa çıkma zorluğu alt boyutundan daha düşük puan aldıkları belirlenmiştir. Covid-19'un anksiyete ve stres yarattığını düşünen öğrencilerin hastalığın korkunçluğu alt boyutu ve hastalık olasılığı alt boyutundan $(14.74 \pm 3.75)$ anksiyete ve stres yaratmadığını düşünen öğrencilere göre daha yüksek puan aldıkları $(11.62 \pm 3.58)$ ve aralarındaki ilişkinin anlamlı olduğu $(p=0.000)$ saptanmıştır. Sağlık Bilişleri Ölçeği genel toplam puanı ile öğrencilerin yaşadıkları yer arasında anlamlı bir ilişki $(p=0.015)$ saptanmıştır. Evde kalan öğrencilerin yurtta ve ailesinin yanında kalan öğrencilere göre aldıkları puanların sırasıyla daha yüksek olduğu $(62.79 \pm 9.95 ; 62.58 \pm 10.20$; $57.37 \pm 1.06$ ) belirlenmiştir (Tablo 4).

Tablo 5'de öğrencilerin DASS-21 Ölçeği ile Sağlık Bilişleri Ölçeği arasındaki korelasyona bakıldığında; öğrencilerin DASS-21 depresyon alt boyutu Sağlık Bilişleri Ölçeği'nin hastalık olasılığı alt boyutu arasında anlamlı pozitif yönde $(\mathrm{r}=0.166, \mathrm{p}=0.028)$, hastalık ile başa çıkma zorluğu alt boyutu arasında anlamlı negatif yönde $(r=-0.347, p=0.000)$ bir ilișki saptanmıștır. DASS21 Ölçeği anksiyete alt boyutu ile Sağlık Bilişleri Ölçeği hastalık olasılığı alt boyutu arasında da anlamlı pozitif yönde $(r=0.217, p=0.004)$ bir ilişki tespit edilmiştir. DASS-21 Ölçeği stres alt boyutu ile Sağlık Bilişleri Ölçeği hastalık ile başa çıkma zorluğu alt boyutu arasında anlamlı negatif yönde $(\mathrm{r}=-0.282, \mathrm{p}=0.000)$ bir ilişki saptanmıștır. DASS-21 Ölçeği toplam puanı ile Sağlık Bilişleri Ölçeği hastalık olasılığı alt boyutu arasında anlamlı pozitif yönde $(\mathrm{r}=0.171, \mathrm{p}=0.023)$ ve hastalık ile başa çıkma zorluğu alt boyutu arasında anlamlı negatif yönde bir ilişki ( $\mathrm{r}=-0.299, \mathrm{p}=0.000)$ belirlenmiştir.

Tablo 5'de öğrencilerin DASS-21 Ölçeği ile Sağlık Bilişleri Ölçeği arasındaki korelasyona bakıldığında; öğrencilerin DASS-21 depresyon alt boyutu Sağlık Bilişleri Ölçeği'nin hastalık olasılığı alt boyutu arasında anlamlı pozitif yönde $(r=0.166, p=0.028)$, hastalı ile başa çıkma zorluğu alt boyutu arasında anlamlı negatif yönde ( $\mathrm{r}=-0.347, \mathrm{p}=0.000)$ bir ilişki saptanmıştır. DASS21 Ölçeği anksiyete alt boyutu ile Sağlık Bilişleri Ölçeği hastalık olasılığ yönde $(\mathrm{r}=0.217, \mathrm{p}=0.004)$ bir ilişki tespit edilmiştir. DASS-21 Ölçeği stres alt boyutu ile Sağlık Biliş̧leri Ölçeği hastalık ile başa çıkma zorluğu alt boyutu arasında anlamlı negatif yönde $(\mathrm{r}=-0.282, \mathrm{p}=0.000)$ bir ilişki saptanmıştır. DASS-21 Ölçeği toplam puanı ile Sağlık Bilişleri Ölçeği hastalık olasılığı alt boyutu arasında anlamlı pozitif yönde $(\mathrm{r}=0.171, \mathrm{p}=0.023)$ ve hastalık ile başa çıkma zorluğu alt boyutu arasında anlamlı negatif yönde bir ilişki ( $\mathrm{r}=-0.299, \mathrm{p}=0.000)$ belirlenmiştir.

\subsection{Tartışma}

Sağlık profesyonelleri arasında yapılan çalışmalarda daha önceki salgınlarda şiddetli akut solunum sendromu (SARS) gibi DASS-21 depresyon anksiyete stres skorlarının yüksek ancak genel halka göre oranların daha düşük olduğu belirtilmektedir [11]. Anksiyete depresyon skorların yüksek olması bireylerin psikolojik iyi olma halinin olumsuz etkilendiğini göstermektedir [15, 16]. Covid-19 pandemisinin hem sahada çalışan hemşireler hem de geleceğin hemşireleri olacak olan hemşirelik öğrencileri için anksiyete, korku, stres, üzüntü, öfke duygu durumlarını değiştireceği ve bu anlamda sağlık bilişlerini düzeyini etkileyeceğinin kaçınılmaz olduğu düşünülmektedir. $\mathrm{Bu}$ nedenle bu çalışmada Covid-19 pandemi sürecinde hemşirelik öğrencileri arasında depresyon anksiyete stres ve sağlık bilişleri arasındaki ilişki literatürle tartışılmıştır.

Çalışmamızda kadın öğrencilerin erkek öğrencilere göre DASS-21 Ölçeği anksiyete alt boyut puanlarının daha yüksek ve aralarındaki farkın istatistiksel olarak anlamlı olduğu saptanmıştır. Literatür incelendiğinde çalışma bulgularımızla benzer sonuçların olduğu; kadın hemşirelik öğrencilerin erkeklerden daha şiddetli anksiyete ve korku yaşadıklarını gösteren çalışmalar görülmektedir [17]. Bu sonuçlar bize hemşirelik öğrencilerinin çoğunluğunun kadınlardan oluştuğu göz önüne alındığında kadınların ailelerini koruma endişe içinde olduklarını ve bu nedenle erkeklere oranla daha fazla anksiyete ve stres yaşadıklarını düşündürmektedir. 
Tablo 4. Hemşirelik Öğrencilerinin DASS-21 ve Sağlık Bilişleri Ölçeği’nden Aldıkları Puanların Bazı Değişkenler Açısından Karşılaştırılması (n=175)

\begin{tabular}{|c|c|c|c|c|c|c|c|c|c|}
\hline Değişken & Depresyon & Anksiyete & Stres & $\begin{array}{l}\text { DASS-21 } \\
\text { Toplam }\end{array}$ & $\begin{array}{l}\text { Hastalık } \\
\text { olasılığı }\end{array}$ & $\begin{array}{c}\text { Hastalığın } \\
\text { korkunçluğu }\end{array}$ & $\begin{array}{c}\text { Hastalık ile } \\
\text { başa çıkma } \\
\text { zorluğu }\end{array}$ & $\begin{array}{c}\text { Sağlık } \\
\text { hizmetlerinin } \\
\text { yetersizliği }\end{array}$ & $\begin{array}{l}\text { Sağlık Bilişleri } \\
\text { Ölçeği Toplam }\end{array}$ \\
\hline $\begin{array}{l}\text { Cinsiyet } \\
\text { Kadın } \\
\text { Erkek }\end{array}$ & $\begin{array}{l}5.19 \pm 5.54 \\
9.37 \pm 8.70\end{array}$ & $\begin{array}{l}3.08 \pm 2.84 \\
1.22 \pm 1.28\end{array}$ & $\begin{array}{l}7.51 \pm 5.93 \\
6.96 \pm 3.34\end{array}$ & $\begin{array}{l}15.34 \pm 11.93 \\
16.92 \pm 11.03\end{array}$ & $\begin{array}{l}14.38 \pm 3.84 \\
13.00 \pm 4.09\end{array}$ & $\begin{array}{l}14.38 \pm 3.84 \\
13.00 \pm 4.09\end{array}$ & $\begin{array}{l}25.20 \pm 5.03 \\
25.74 \pm 3.96\end{array}$ & $\begin{array}{l}11.27 \pm 2.71 \\
10.37 \pm 1.98\end{array}$ & $\begin{array}{c}62.68 \pm 10.42 \\
60.96 \pm 6.41\end{array}$ \\
\hline $\begin{array}{l}\text { Test istatistiği } \\
\mathbf{z} / \mathbf{p}\end{array}$ & $\begin{array}{l}\mathrm{z}=-1.928 \\
\mathrm{p}=0.054\end{array}$ & $\begin{array}{l}\mathrm{Z}=-3.221 \\
\mathbf{p}=\mathbf{0 . 0 0 1}\end{array}$ & $\begin{array}{l}\mathrm{z}=-0.141 \\
\mathrm{p}=0.888\end{array}$ & $\begin{array}{l}\mathrm{z}=-1.059 \\
\mathrm{p}=0.290\end{array}$ & $\begin{array}{l}z=-1.766 \\
p=0.077\end{array}$ & $\begin{array}{l}z=-1.766 \\
p=0.077\end{array}$ & $\begin{array}{l}\mathrm{z}=-0.071 \\
\mathrm{p}=0.944\end{array}$ & $\begin{array}{l}\mathrm{z}=-1.687 \\
\mathrm{p}=0.092\end{array}$ & $\begin{array}{l}\mathrm{z}=-1.517 \\
\mathrm{p}=0.129\end{array}$ \\
\hline $\begin{array}{l}\text { Yaşadığı Yer } \\
\text { Yurt }^{\mathrm{a}} \\
\mathrm{Ev}^{\mathrm{b}} \\
\text { Aile yanı }\end{array}$ & $\begin{array}{l}5.67 \pm 6.04 \\
5.90 \pm 6.31 \\
7.50 \pm 9.53\end{array}$ & $\begin{array}{l}2.84 \pm 2.79 \\
2.70 \pm 2.78 \\
2.75 \pm 1.90\end{array}$ & $\begin{array}{l}7.43 \pm 5.68 \\
7.17 \pm 5.55 \\
9.25 \pm 5.41\end{array}$ & $\begin{array}{l}15.53 \pm 11.93 \\
15.37 \pm 11.82 \\
18.00 \pm 10.35\end{array}$ & $\begin{array}{l}13.89 \pm 3.93 \\
14.25 \pm 3.85 \\
17.12 \pm 2.90\end{array}$ & $\begin{array}{l}13.89 \pm 3.93 \\
14.25 \pm 3.85 \\
17.12 \pm 2.90\end{array}$ & $\begin{array}{l}25.51 \pm 4.94 \\
25.35 \pm 4.87 \\
21.75 \pm 2.60\end{array}$ & $\begin{array}{c}11.32 \pm 2.62 \\
11.14 \pm 2.55 \\
8.62 \pm 2.13\end{array}$ & $\begin{array}{l}62.58 \pm 10.20 \\
62.79 \pm 9.95 \\
57.37 \pm 1.06\end{array}$ \\
\hline $\begin{array}{l}\text { Test istatistiği } \\
\mathbf{x}^{2} / p\end{array}$ & $\begin{array}{l}x^{2}=0.107 \\
p=0.948\end{array}$ & $\begin{array}{c}x^{2}=0.266 \\
p=0.875\end{array}$ & $\begin{array}{c}x^{2}=1.490 \\
p=0.475\end{array}$ & $\begin{array}{c}x^{2}=0.487 \\
p=0.784\end{array}$ & $\begin{array}{l}\mathrm{x}^{2}=5.832 \\
\mathrm{p}=0.054\end{array}$ & $\begin{array}{l}\mathrm{x}^{2}=5.832 \\
\mathrm{p}=0.054\end{array}$ & $\begin{array}{c}x^{2}=8.144 \\
\mathbf{p}=\mathbf{0 . 0 1 7}\end{array}$ & $\begin{array}{c}x^{2}=7.030 \\
\mathbf{p}=\mathbf{0 . 0 3 0}\end{array}$ & $\begin{array}{l}x^{2}=8.399 \\
\mathbf{p}=\mathbf{0 . 0 1 5}\end{array}$ \\
\hline Çoklu karşılaştırma & $c>b>a$ & $c>b>a$ & $c>b>a$ & $c>b>a$ & $b>a>c$ & $c>b>a$ & $\mathbf{b}>\mathbf{c}>\mathbf{a}$ & $\mathbf{a}>\mathbf{b}>\mathbf{c}$ & $\mathbf{b}>\mathbf{c}>\mathbf{a}$ \\
\hline $\begin{array}{l}\text { Covid-19 hakkında } \\
\text { eğitim alma durumu } \\
\text { Evet } \\
\text { Hayır }\end{array}$ & $\begin{array}{l}6.40 \pm 7.00 \\
5.64 \pm 6.05\end{array}$ & $\begin{array}{l}2.56 \pm 2.82 \\
2.87 \pm 2.72\end{array}$ & $\begin{array}{l}6.84 \pm 5.75 \\
7.62 \pm 5.57\end{array}$ & $\begin{array}{l}15.31 \pm 10.59 \\
15.67 \pm 12.19\end{array}$ & $\begin{array}{l}13.70 \pm 3.18 \\
14.32 \pm 4.11\end{array}$ & $\begin{array}{l}13.70 \pm 3.18 \\
14.32 \pm 4.11\end{array}$ & $\begin{array}{l}26.25 \pm 3.11 \\
24.96 \pm 5.31\end{array}$ & $\begin{array}{l}10.27 \pm 2.36 \\
11.42 \pm 2.65\end{array}$ & $\begin{array}{c}62.36 \pm 6.48 \\
62.43 \pm 10.84\end{array}$ \\
\hline $\begin{array}{l}\text { Test istatistiği } \\
\mathrm{z} / \mathrm{p}\end{array}$ & $\begin{array}{l}\mathrm{z}=-0.213 \\
\mathrm{p}=0.831\end{array}$ & $\begin{array}{l}\mathrm{z}=-0.935 \\
\mathrm{p}=0.350\end{array}$ & $\begin{array}{l}z=-0.954 \\
p=0.340\end{array}$ & $\begin{array}{l}\mathrm{z}=-0.186 \\
\mathrm{p}=0.853\end{array}$ & $\begin{array}{l}\mathrm{z}=-1.528 \\
\mathrm{p}=0.127\end{array}$ & $\begin{array}{l}\mathrm{z}=-1.528 \\
\mathrm{p}=0.127\end{array}$ & $\begin{array}{l}\mathrm{z}=-1.250 \\
\mathrm{p}=0.211\end{array}$ & $\begin{array}{l}z=-2.931 \\
\mathbf{p}=\mathbf{0 . 0 0 3}\end{array}$ & $\begin{array}{l}z=-0.992 \\
p=0.321\end{array}$ \\
\hline $\begin{array}{l}\text { Covid-19'un anksiyete } \\
\text { ve stres yaratma } \\
\text { durumu } \\
\text { Evet }\end{array}$ & $5.91 \pm 6.36$ & $2.86 \pm 2.78$ & $7.72 \pm 5.66$ & $16.04 \pm 12.07$ & $14.74 \pm 3.75$ & $14.74 \pm 3.75$ & $25.00 \pm 4.55$ & $11.25 \pm 2.62$ & $62.59 \pm 9.72$ \\
\hline Hayır & $5.50 \pm 6.04$ & $2.50 \pm 2.60$ & $6.12 \pm 5.27$ & $13.56 \pm 10.27$ & $11.62 \pm 3.58$ & $11.62 \pm 3.58$ & $26.53 \pm 6.06$ & $10.62 \pm 2.61$ & $61.62 \pm 10.85$ \\
\hline $\begin{array}{l}\text { Test istatistiği } \\
\mathrm{z} / \mathrm{p}\end{array}$ & $\begin{array}{l}\mathrm{z}=-0.447 \\
\mathrm{p}=0.655\end{array}$ & $\begin{array}{l}\mathrm{z}=-0.678 \\
\mathrm{p}=0.498\end{array}$ & $\begin{array}{l}\mathrm{z}=-1.419 \\
\mathrm{p}=0.156\end{array}$ & $\begin{array}{l}z=-0.904 \\
p=0.366\end{array}$ & $\begin{array}{l}z=-3.981 \\
\mathbf{p}=\mathbf{0 . 0 0 0}\end{array}$ & $\begin{array}{l}\mathrm{z}=-3.981 \\
\mathbf{p}=\mathbf{0 . 0 0 0}\end{array}$ & $\begin{array}{l}\mathrm{z}=-2.392 \\
\mathbf{p}=\mathbf{0 . 0 1 7}\end{array}$ & $\begin{array}{l}\mathrm{z}=-0.622 \\
\mathrm{p}=0.534\end{array}$ & $\begin{array}{l}\mathrm{z}=-0.485 \\
\mathrm{p}=0.627\end{array}$ \\
\hline
\end{tabular}


Tablo 5. Hemşirelik Öğrencilerinin DASS-21 ve Sağlık Bilişleri Ölçeği’nden Aldıkları Puanların Korelasyonu $(\mathrm{n}=175)$

\begin{tabular}{|c|c|c|c|c|c|c|c|c|}
\hline \multirow{3}{*}{$\begin{array}{l}\text { Sağlık Bilişleri } \\
\text { Ölçeği (SBÖ) }\end{array}$} & \multicolumn{8}{|c|}{ DASS-21 } \\
\hline & \multicolumn{2}{|c|}{ Depresyon } & \multicolumn{2}{|c|}{ Anksiyete } & \multicolumn{2}{|c|}{ Stres } & \multicolumn{2}{|c|}{ DASS-21 Toplam } \\
\hline & $\mathrm{r}$ & $\mathrm{p}$ & $\mathrm{r}$ & $\mathrm{p}$ & $\mathrm{r}$ & $\mathrm{p}$ & $\mathrm{r}$ & $\mathrm{p}$ \\
\hline Hastalık Olasılığı & 0.166 & $0.028^{*}$ & 0.217 & $0.004 * *$ & 0.080 & 0.290 & 0.171 & $0.023 *$ \\
\hline $\begin{array}{l}\text { Hastalığın } \\
\text { Korkunçluğu }\end{array}$ & 0.141 & 0.063 & 0.058 & 0.445 & 0.136 & 0.074 & 0.146 & 0.053 \\
\hline $\begin{array}{l}\text { Hastalık ile Başa } \\
\text { Çıkma Zorluğu }\end{array}$ & -0.347 & $0.000^{* *}$ & -0.094 & 0.216 & -0.282 & $0.000^{* *}$ & -0.299 & $0.000^{* * *}$ \\
\hline $\begin{array}{l}\text { Sağlık } \\
\text { Hizmetlerinin } \\
\text { Yetersizliği }\end{array}$ & -0.058 & 0.444 & 0.074 & 0.333 & 0.063 & 0.407 & 0.021 & 0.780 \\
\hline SBÖ Toplam & -0.044 & 0.561 & 0.087 & 0.254 & -0.045 & 0.556 & -0.017 & 0.822 \\
\hline
\end{tabular}

Çalışmamızda kadın öğrencilerin erkek öğrencilere göre DASS-21 Ölçeği stres alt boyut puanlarının daha yüksek olduğu tespit edilmiştir. Yapılan çalışmalarda kadınların stres puanlarının erkeklerden daha yüksek olduğu bulunmuştur $[18,19,20]$. Bu bulgular cinsiyetin meslekte önemli olmadığını ancak pandemi döneminde sosyokültürel faktörler nedeniyle kadınların daha fazla stres yaşadıklarını göstermektedir.

Çalışmamızda hemşirelik öğrencilerinin \%12.6'sının hafif, \%12.6'sinın orta ve \%8.6'sinın ileri düzey ve \%25.1'inin çok ileri düzey depresyon yaşadıkları; anksiyetenin ise \%9.7'sinde hafif ve \%13.2'sinde orta düzey olduğu; stresi ise, \%9.7'sinin hafif, \%16.6'sının orta, \%13.1'inin ileri ve \%7.4'ünün ise çok ileri düzeyde yaşadığı tespit edilmiştir. Çin'de COVID-19 hastalarını tedavi eden sağlık çalışanları arasında yapılan bir çalışmada katılımcılarda \%50,4, \%44,6 ve \%34,0 depresyon, anksiyete ve stres belirtileri gözlemlenmiştir [20]. Bu çalışma sonuçları bize kadınların erkeklere göre duygusal anlamda daha hassas olduklarını, daha çabuk etkilendiklerini ve duygu odaklı yaklaşım sergilediklerini de düşündürmektedir. Literatür incelendiğinde çalışma bulgularımızla benzer sonuçların yer aldığı COVİD-19 salgınında yapılan bir çalışmada DASS-21 puanlama sistemine göre katılımcıların \%15.7'sinde anksiyete, \%10,6'sinda depresyon, \%5,2 'sinde ise stres olduğu saptanmıştır [21]. Çin'de lisans hemşirelik öğrencilerinde yapılan bir çalışmada son sınıf hemşirelik öğrencilerin anksiyete ve depresyon düzeylerinin yüksek, esenlik ve başa çıkma mekanizmalarının düşük olduğu saptanmıştır [22]. Yapılan başka bir çalışmada anksiyete ve depresif belirtiler arttıkça psikolojik iyi olma halinin azaldığ yapılan bir çalışmaya göre daha önce yaşanan şiddetli akut solunum sendromu salgınında (SARS) sağlık çalışanları arasında hemşirelerin daha fazla stres yaşadıkları saptanmıştır [23]. Benzer bir çalışmada sağlık çalışanlarının SARS salgınında yaşadığı olumsuz duyguları (enfeksiyon riski, hastalarla yakın temastan

oluşan bulaş korkusu, sağlık hizmetlerinde artan yük) Covid-19 salgınında da yaşadıkları ve stres düzeylerinin arttığı saptanmış [24, 25]. Bu çalışma sonuçları bize salgın hastalık durumunun bireylerin ruh halini etkilediği ve hemşirelik öğrencilerinin ruh sağlıkları korumak için sağlık biliş düzeylerinin artırılması gerektiği düşünülmektedir.

Çalışma bulgularımıza göre, DASS-21 ölçeği depresyon alt boyutu ile Sağlık Bilişleri Ölçeği'nin hastalık olasılığı alt boyutu arasında anlamlı pozitif, hastalık ile başa çıkma zorluğu alt boyutu arasında anlamlı negatif yönde bir ilişki olduğu saptanmıştır. DASS-21 Ölçeği anksiyete alt boyutu ile Sağlık Bilişleri Ölçeği hastalık olasılığı alt boyutu arasında da anlamlı pozitif yönde bir ilișki tespit edilmiştir. DASS-21 Ölçeği toplam puanı ile Sağlık Bilişleri Ölçeği hastalık olasılığı alt boyutu ile arasında anlamlı pozitif yönde bir ilişki ve hastalık ile başa çıkma zorluğu alt boyutu arasında anlamlı negatif yönde bir ilişki belirlenmiştir. Çalışma bulgularımızı destekleyen benzer literatür desteğine ulaşılamamıştır.

Çalışmada öğrencilerde Covid-19'un anksiyete ve stres yaratma durumu ile hastalıkla başa çıkma zorluğu alt boyutu arasında da anlamlı bir ilişki tespit edilmiştir $(\mathrm{p}=0.017)$. Covid-19 anksiyete ve stres yaratyor diyen öğrencilerin yaratmıyor diyen öğrencilere göre hastalıkla başa çıkma zorluğu alt boyutundan daha düşük puan aldıkları belirlenmiştir. Covid-19'un anksiyete ve stres yarattığını düşünen öğrencilerin hastalığın korkunçluğu alt boyutu ve hastalık olasılığı alt boyutundan anksiyete ve stres yaratmadığını düşünen öğrencilere göre daha yüksek puan aldıkları ve aralarındaki ilişkinin anlamlı olduğu $(p=0.000)$ saptanmıştır. Hemşirelik öğrencileri arasında yapılan bir çalışmada psikolojik iyi olma düzeyleri ile başa çıkma, umutsuzluk, çaresizlik, kendini suçlama arasında negatif bir ilişki tespit edilmiştir [26]. 
Yapılan başka bir çalışmada ise Covid-19 salgını ile birlikte doktor ve hemşirelerin de anksiyete, stres ve depresyon düzeylerinde artışa neden olduğu bulunmuştur [27]. Yavuzer ve Karataş tarafından yapılan çalışmada, negatif otomatik düşüncelerin, genç yetişkinlerin depresyon düzeyini açıklamada önemli yordayıcılar olduğunu belirtmektedir [28]. Yapılan diğer araştırmalarda psikolojik iyilik hali, çaresizlik ve umutsuzluk arasında anlamlı negatif bir ilişki olduğunu göstermiştir [29, 30]. Bu çalışma sonuçları bize hemşirelik öğrencilerinin sağlık biliş düzeyleri, sağlığı nasıl algıladıklarının önemli olduğunu ve bu nedenle sağlı biliş düzeylerinin eğitimler ve becerilerle artırılarak yaşanacak anksiyete, stres ve depresyonu önlemede etkili olacağını düşündürmektedir.

\subsection{Sinırlamalar}

Çalışma sonuçların genellenebilirliği yoktur çünkü çalışma örneği sadece araştırma yapılan okuldaki hemşirelik ögrencilerinden oluşmaktadır. Online olması nedeniyle evrenin tümüne ulaşılamamıştır sonuçlar sadece örneklem kadarını göstermektedir. Gelecekteki çalışmalar için bu konuyu daha çok öğrenci sayısı ve farklı değişkenler açısından araştırılması tavsiye edilebilir.

\section{Sonuc}

Bu çalışmanın sonuçları, pandemi döneminde hemşirelik öğrencilerinde depresyon anksiyete stres ve sağlık bilişı arasında bir ilişki olduğunu göstermiştir. Hemşirelik öğrencilerinin sağlık biliş algılarının saptanması, sağlık algilarının anksiyete, depresyon ve stres durumlarına etkisinin belirlenmesi, öğrencilerin kliniklerde hasta bireylerle karşılaşacak olmaları ve kendilerinin ve çevrelerinin de sağlıklı yaşam koşullarını kazanmaları açısından önemli olduğu düşünülmektedir. Bu çalışmadan elde edilen bulgular, pandemi döneminde anksiyete, depresyon, stres belirtileri olan öğrencilerin sağlık bilişi düzeylerinin güçlendirilmesi açısından hemşire eğitimcilerin ve klinik eğitmenlerin önemli rolleri olduğunu göstermektedir. Hemşire eğiticiler ve klinik eğitmenler hemşirelik öğrencilerinin sağlık bilişlerini yükseltmek için hizmet içi eğitim programları düzenlemeli, farkındalıklarını artırmalı ve öğrencilere psikolojik destek sağlanması konusunda yardımcı olmalıdırlar.

\section{Referanslar}

1. Zhu, N, Zhang, D, Wang, W, Li, X, Yang, B, Song, J, et al., A nove coronavirus from patients with pneumonia in China 2019, The New England Journal Medicine, 2020, 382(8),727-733.

2. Habibzadeh, P, Stoneman, E.K, The Novel Coronavirus: A Bird's Eye View, International Journal of Occupatioanl and Environmenta Medicine, 2020, 11(2), 65-71.

3. Gorbalenya, A.E, Severe acute respiratory syndrome-related coronavirus-The species and its viruses, a statement of the Coronavirus Study Group, BioRxiv, 2020.

4.Covid-19 rehberi. https.sağlıkbakanlıgı.gov.tr. Erişim:16.09.2020.

5. Lai, C.C, Shih, TP, Ko, W.C, Tang, H.J, Hsueh, P.R, Severe acute respiratory syndrome coronavirus 2 (SARS-CoV-2) and corona virus disease-2019 (COVID-19): the epidemic and the challenges, Interna Journal of Antimicrobial Agents, 2020, 55(3),105924.

6. Huang, C, Wang, Y, Li, X, Ren, L, Zhao, J, Hu, Y, et al, Clinica features of patients infected with 2019 novel coronavirus in Wuhan, China, Lancet, 2020, 395(10223),497-506.
7. Bai, Y, Yao, L, Wei, T, Tian, F, Jin, D.Y, Chen, L, et al., Presumed Asymptomatic Carrier Transmission of COVID-19, The Journal of the American Medical Association, 2020 Feb 21. doi: 10.1001/jama.2020.2565

8. Biscayart, C, Angeleri, P, Lloveras, S, Chaves, T, Schlagenhauf, P, Rodríguez-Morales, A.J, The next big threat to global health? 2019 novel coronavirus (2019-nCoV): What advice can we give to travellers? Interim recommendations January 2020, from the LatinAmerican society for Travel Medicine (SLAMVI). Travel Medicine and Infectious Disease, 2020, 33, 101567.

9. Taghrir, M.H, Borazjani, R, Shiraly, R, COVID-19 and Iranian Medical Students; A Survey on Their Related-Knowledge, Preventive Behaviors and Risk Perception, Arch Iran Med March, 2020, 23(4),249-254.

10. Hadjistavropoulos, H.D, Janzen, J.A, Kehler, M.D, Leclerc, J.A, Sharpe, D, Bourgault-Fagnou, M.D, Core cognitions related to health anxiety in self-reported medical and non-medical samples. Journal of Behavioral Medicine, 2012, 35(2),167-178.

11. Lai, J, Ma, S, Wang, Y, Cai, Z, Hu, J, Wei, N, et al., Factors associated with mental health outcomes among health care workers exposed to coronavirus disease 2019, The Journal of the American Medical Association, 2020, 3(3), e203976-e203976.

12. Altay, D, Yuksel, M, Sağlık Bilișleri Ölçeği: Geçerlilik ve Güvenilirlik Çalışması. V. Turkcess Uluslararası Eğitim ve Sosyal Bilimler Kongresi'nde Sunulan Tam Metin Kitapçı̆̆ı, 2019, 286-295, İstanbul, Türkiye.

13. Yılmaz, Ö, Boz, H, Arslan, A, Depresyon Anksiyete Stres Ölçeğinin (Dass 21) Türkçe Kısa Formunun Geçerlilik-Güvenilirlik Çalışması, Finasn Ekonomi ve Sosyal Araştrımalar Dergisi, 2017,2(2), 78-91.

14. Lovibond, P.F. \& Lovibond, S.H, The structure of negative emotional states: Comparison of the Depression Anxiety Stress Scales (DASS) with the Beck Depression and Anxiety Inventories, Behaviour Research and Therapy, 1995, 33(3), 335-343.

15. Udhayakumar, P, Illango, P, Psychological wellbeing among college students, Journal of Social Work Education and Practice, 2018, 3, 79-89.

16. Ramkisson, S, Pillay, B.J, Sartorius, B, Anxiety, depression and psychological well-being in a cohort of South African adults with type 2 diabetes mellitus, South African Journal of Psychiatry, 2016, 22, 935

17. Huang, L, Xu, F, Liu, H, Yu, L, Emotional responses and coping strategies of nurses and nursing college students during COVID-19 outbreak: A comparative study. Plos One, 2020, 15(8),e02237303

18. Anbumalar, C, Agines, D, Jaswanti, V.P, Priya, D, Reniangelin, D, Gender differences in perceived stress levels and coping strategies among college students, The International Journal of Indian Psychology, 2017, 4(4),22-33.

19. Torres-Montiel, S, Pelaez-Hernandez, V, Robles-Uribe, B, PerezCaba-As, E, Figueroa-Herrera, F, Orea-Tejeda, A. ve ark., Gender differences in perceived stress, psychological well-being and therapeutic compliance, European Respiratory Journal, 2017, 50, PA3897.

20. Lai, J, Ma Simeng, Wang Y, Cai Z, Hu J, Wei N, et al., Factors Associated With Mental Health Outcomes Among Health CareWorkers Exposed to Coronavirus Disease 2019. The Journal of the American Medical Association, 2020,3(3),e203976.

21. Chew, N.W, Lee, G.K, Tan, B.Y, Jing, M, Goh, Y, Ngiam, N. J, et al., Multinational, multicentre study on the psychological outcomes and associated physical symptoms amongst healthcare workers during COVID-19 outbreak, Brain, Behavior, and Immunity, 2020, 88, 559565.

22. Smith, G.D, Yang, F, Stress, resilience and psychological well being in Chinese undergraduate nursing students, Nurse Education Today, 2017, 49, 90-95.

23. Chan, A.O, Huak, C.Y, Psychological impact of the 2003 severe acute respiratory syndrome outbreak on health care workers in a medium size regional general hospital in Singapore, Occupational Medicine, 2004, 54(3), 190-196.

24. Adams, J.G, Walls, R.M, Supporting the Health Care Workforce During the COVID-19 Global Epidemic The Journal of the American Medical Association, 2020, 323(15), 1439-1440.

25. Sim Malcolm, R, The COVID-19 pandemic: major risks to healthcare and other workers on the front line, Occupational and Environmental Medicine, 2020, 281-282.

26. Yüksel, A, Bahadir-Yilmaz, E, Relationship between Depression, Anxiety, Cognitive Distortions, and Psychological Well-Being 
among Nursing Students, Perspectives in Psychiatric Care, 2019, 55(4),690-696,

27. Kang, L, Ma, S, Chen M, Yang, J, Wang, Y, Li, R, et al., Impact on mental health and perceptions of psychological care among medical and nursing staff in Wuhan during the 2019 novel coronavirus disease outbreak: A cross-sectional study, Brain, Behavior, and Immunity, 2020, 87, 11-17.

28. Yavuzer, Y, Karatas, Z, Investigating the relationship between depression, negative automatic thoughts, life satisfaction and symptom interpretation in Turkish young adults, In: D , Breznoscakova,eds, Depression, Croatia， Rijeka: Intech Open; 2018, pp 71-89.

29. Dirzyte, A, Patapas, A, Determinants of subjective wellbeing: Lithuanian case, European Scientific Journal, 2015, 11,138.

30. Singh, A.K, Singh, S, Singh, A.P, Srivastava A, Hope and well being among students of Professional courses, Indian Journal Community Psychology, 2013, 9,109-119.

http://edergi.cbu.edu.tr/ojs/index.php/cbusbed isimli yazarın CBU-SBED başlıklı eseri bu Creative Commons Alıntı-Gayriticari4.0 Uluslararası Lisansı ile lisanslanmıştır.
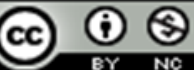